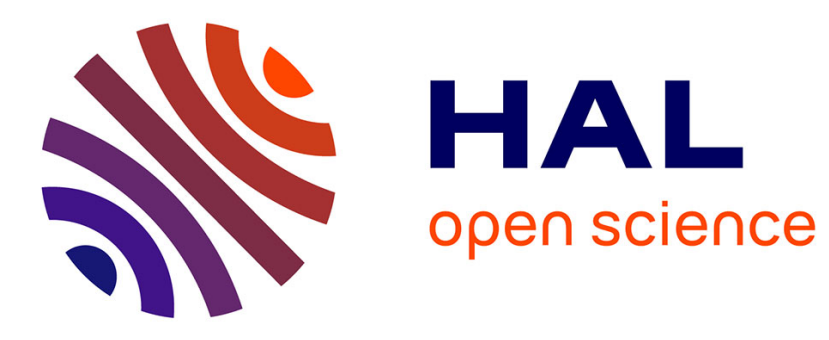

\title{
Mn2+-dependent ADP-ribose/CDP-alcohol pyrophosphatase: a novel metallophosphoesterase family preferentially expressed in rodent immune cells
}

José Canales, Ascensión Fernández, João Meireles Ribeiro, Alicia Cabezas, Joaquim Rui Rodrigues, José Carlos Cameselle, María Jesús Costas

\section{To cite this version:}

José Canales, Ascensión Fernández, João Meireles Ribeiro, Alicia Cabezas, Joaquim Rui Rodrigues, et al.. Mn2+-dependent ADP-ribose/CDP-alcohol pyrophosphatase: a novel metallophosphoesterase family preferentially expressed in rodent immune cells. Biochemical Journal, 2008, 413 (1), pp.103-113. 10.1042/BJ20071471 . hal-00478903

\section{HAL Id: hal-00478903 https://hal.science/hal-00478903}

Submitted on 30 Apr 2010

HAL is a multi-disciplinary open access archive for the deposit and dissemination of scientific research documents, whether they are published or not. The documents may come from teaching and research institutions in France or abroad, or from public or private research centers.
L'archive ouverte pluridisciplinaire HAL, est destinée au dépôt et à la diffusion de documents scientifiques de niveau recherche, publiés ou non, émanant des établissements d'enseignement et de recherche français ou étrangers, des laboratoires publics ou privés. 


\title{
$\mathrm{Mn}^{2+}$-dependent ADP-ribose/CDP-alcohol pyrophosphatase: a novel metallophosphoesterase family preferentially expressed in rodent immune cells*
}

\section{José CANALES, Ascensión FERNÁNDEZ, João Meireles RIBEIRO, Alicia CABEZAS, Joaquim Rui RODRIGUES, ${ }^{1}$ José Carlos CAMESELLE $^{2}$ and María Jesús COSTAS ${ }^{3}$}

Grupo de Enzimología, Departamento de Bioquímica y Biología Molecular y Genética, Facultad de Medicina, Universidad de Extremadura, 06080 Badajoz, Spain

Running title: $\mathrm{Mn}^{2+}$-dependent ADP-ribose/CDP-alcohol pyrophosphatase

\begin{abstract}
Abbreviations used: ADPRibase, ADP-ribose pyrophosphatase (used only for rat enzymes); GST, glutathione S-transferase; MALDI, matrix assisted laser desorption/ionisation; NDP, nucleoside 5'-diphosphate; NDP-X, nucleoside 5'diphosphate-X; NMP, nucleoside 5'-monophosphate; ORF, open reading frame; TRPM2, transient receptor potential melastatin channel-2.
\end{abstract}

The DNA sequence reported in this paper has been deposited in GenBank under accession number EU037900.

Figures S1-S6 and Table S1 are included in the online supplement.

* Dedicated to Antonio Sillero, our teacher, on his $70^{\text {th }}$ anniversary

${ }^{1}$ On leave from the Escola Superior de Tecnologia e Gestão, Instituto Politécnico de Leiria, Leiria, Portugal

${ }^{2,3}$ To whom correspondence should be addressed (email camselle@ unex.es ${ }^{2}$ and macostas@unex.es ${ }^{3}$ ) 


\section{SYNOPSIS}

The $\mathrm{Mn}^{2+}$-dependent ADP-ribose/CDP-alcohol pyrophosphatase (ADPRibase-Mn) is isolated from rat liver supernatants after separation from $\mathrm{Mg}^{2+}$-activated ADP-ribose pyrophosphatases devoid of CDP-alcohol pyrophosphatase activity (ADPRibase-I and ADPRibase-II). The latter are putative Nudix hydrolases, while the molecular identity of ADPRibase-Mn is unknown. MALDI mass spectrometry data from rat ADPRibaseMn pointed to a hypothetical protein that was cloned and expressed, and showed the expected specificity. It is encoded by the $R G D 1309906$ rat gene, so far annotated just as 'hydrolase'. ADPRibase-Mn is not a Nudix hydrolase, but it shows the sequence and structural features typical of the metallophosphoesterase superfamily. It may constitute a protein family of their own, which appears to be specific to vertebrates, plants and algae. ADP-ribose was successfully docked to a model of rat ADPRibase-Mn revealing its putative active centre. Microarray data from the GEO database indicated the mouse gen 2310004124Rik, orthologous of RGD1309906, is preferentially expressed in immune cells. This was confirmed by northern and activity assay of ADPRibase-Mn in rat tissues. A possible role of ADPRibase-Mn in immune cell signaling is suggested by the second messenger role of ADP-ribose, that activates TRPM2 ion channels as a mediator of oxidative/nitrosative stress, and by the signaling function assigned to many of the microarray profile neighbours of 2310004I24Rik. Furthermore, an influence of ADPRibase-Mn in the CDP-choline or CDP-ethanolamine pathways of phospholipid biosynthesis cannot be discarded.

Key words: ADP-ribose, CDP-choline, metallophosphoesterase, Nudix, immune system, signalling. 


\section{INTRODUCTION}

ADP-ribose is part of the $\mathrm{NAD}(\mathrm{P})$-derived network of regulators. It is a primary product of NAD, formed by hydrolysis of the $\mathrm{N}$-glycosidic linkage between nicotinamide and ribose, and also a secondary product formed by turnover of NAD primary metabolites $[1,2]$. Its reducing ribose moiety is prone to react nonenzymically, which explains its protein-glycating character and its reputation of being cytotoxic [3-5]. On the other hand, intracellular ADP-ribose is also a regulator of ion channels. Very interesting is the role of ADP-ribose as an activator of transient receptor potential melastatin channel-2 (TRPM2) that participates in $\mathrm{Ca}^{2+}$-mediated cell death. The channel opens in response to ADP-ribose as a mediator of oxidative/nitrosative stress in the immune system, a major site for TRPM2 expression [6-11].

ADP-ribose levels in mammals are likely controlled by a low- $K_{\mathrm{m}}, \mathrm{Mg}^{2+}-$ dependent, specific ADP-ribose pyrophosphatase [6, 12-15], that belongs to the Nudix superfamily of NDP-X hydrolases [16, 17]. However, there are other mammalian ADPribose hydrolases with diverse preferences for NDP-X substrates and for $\mathrm{Mg}^{2+}$ or $\mathrm{Mn}^{2+}$ as activators. In rat liver, ADP-ribose can be hydrolysed by the broad-specificity nucleotide pyrophosphatase or phosphodiesterase I ectoenzymes [18] and four intracellular hydrolases [19, 20]. ADPRibase-I (cytosolic) and ADPRibase-m (mitochondrial) are specific ADP-ribose pyrophosphatases that hydrolyse only ADPribose and the non-physiological IDP-ribose in the presence of $\mathrm{Mg}^{2+}$. Their specificity is less strict in the presence of $\mathrm{Mn}^{2+}$, but $\mathrm{Mg}^{2+}$ is likely to be the physiological activator. ADPRibase-II (cytosolic) is a $\mathrm{Mg}^{2+}$-dependent ADP-sugar pyrophosphatase, also less strict in its NDP-X specificity when assayed with $\mathrm{Mn}^{2+}$. Finally, ADPRibase-Mn is not activated by $\mathrm{Mg}^{2+}$, but by low micromolar $\mathrm{Mn}^{2+}$. Its specificity is unusual, as it hydrolyses ADP-ribose, IDP-ribose, CDP-glycerol, CDP-choline and CDPethanolamine, but not other non-reducing ADP-sugars or CDP-glucose [19].

None of these rat ADP-ribose hydrolases have been cloned, but ADPRibase-I and ADPRibase-m are near identical to human Nudix enzymes NUDT9 $\beta$ and NUDT9 $\alpha$ [6, 13-15, 19-21], both encoded by the NUDT9 gene, while ADPRibase-II is related to human NUDT5 [21, 22], also a Nudix enzyme encoded by the NUDT5 gene. In contrast, ADPRibase-Mn is not molecularly identified. Here, we are showing it forms a novel metallophosphoesterase family preferentially expressed in rodent immune tissues and cells.

\section{EXPERIMENTAL}

Chemicals and biochemicals

1,10-Phenanthroline monohydrate, and sodium salts of ADP-ribose, ADP-glucose, CDP-choline, CDP-ethanolamine, CDP-glycerol, CDP-glucose, UDP-glucose, CDP, AMP and CMP were from Sigma. ADP (potassium salt), Tris base (2-amino-2[hydroxymethyl]-1,3-propanediol) and alkaline phosphatase (grade I from calf intestine) were from Roche. $\mathrm{MnCl}_{2}, \mathrm{MgCl}_{2}, \mathrm{KCl}, \mathrm{NaCl}$, and EDTA (Titriplex ${ }^{\mathrm{TM}} \mathrm{III}$ ) were highpurity preparations from Merck. 
Purification of rat liver ADPRibase-Mn and MALDI mass spectrometry of trypsin digests

Rat ADPRibase-Mn was purified from 100,000 g liver supernatants by a six-step chromatographic procedure. The first five steps were as previously described [19] and, for the final step, the enzyme obtained from $30 \mathrm{~g}$ of liver was adsorbed to a $2.5 \mathrm{~cm} \mathrm{x} 1.5$ $\mathrm{cm}$ Reactive Red 120-agarose column (Sigma) equilibrated in $20 \mathrm{mM}$ Tris- $\mathrm{HCl}, \mathrm{pH} 7.5$, $0.5 \mathrm{mM}$ EDTA, washed with $5 \mathrm{ml}$ of $\mathrm{KCl} 0.5 \mathrm{M}$ in the same buffer, followed by $10 \mathrm{ml}$ of equilibrating buffer. The enzyme $(3.5 \mathrm{ml})$ was recovered with a wash with water and concentrated to $0.1 \mathrm{ml}$ in a centrifugal filter with a $3 \mathrm{~K}$-cutoff polyethersulfone membrane (Filtron Technology Corp, Northborough, MA). This preparation contained a single protein band of $\approx 38 \mathrm{kDa}$. After staining for $1 \mathrm{~h}$ with Coomassie blue G-250 (1 g/l in 50\% methanol) and destaining in $40 \%$ methanol, the band was cut out and processed for trypsin digestion and MALDI mass spectrometry as described [23] (Servicio de Proteómica, UAM, Madrid, Spain). The peptide-mass fingerprint (MS mode), and the ion spectra (MS/MS mode) of two fragments of 1746.88 Da and 2126.98 Da were used for database querying.

\section{PCR cloning and sequencing of rat ADPRibase-Mn cDNA}

The 1014-nt ORF coding for rat ADPRibase-Mn (mRNA accession number BC088174) was amplified by PCR from a rat liver Marathon Ready cDNA preparation with the Advantage $^{\mathrm{TM}}$ cDNA polymerase mix (both from Clontech). The forward primer GTCTGGAATTCCATGGCTGATAAACCGGAC contained an EcoRI site (underlined) followed by $\mathrm{C}$ and the 18 first nucleotides of the ORF, with a designed G12A substitution; the reverse primer GCTCCGTCGACTTATTCCCTTTTGTAATTC contained a SalI site (underlined) followed by the reverse complement of the 19 last nucleotides of the ORF. A product of the expected size was obtained, cut with EcoRI and SalI, and inserted into the corresponding sites of the pGEX-6P-3 plasmid (Amersham) to obtain plasmid pGEX-6P-3-rADPRMn. Both strands of the insert were sequenced in the Servicio de Secuenciación Automática (IIB, CSIC-UAM, Madrid, Spain).

Recombinant ADPRibase-Mn expression and purification

One hundred-ml cultures of BL21 cells transformed with pGEX-6P-3-rADPRMn, were grown at $30^{\circ} \mathrm{C}$ and induced with IPTG. The GST/ADPRibase-Mn fusion recovered in post-sonication supernatants (in $10 \mathrm{ml}$ of $20 \mathrm{mM}$ Tris-HCl, $\mathrm{pH}$ 7.5, $0.5 \mathrm{mM}$ EDTA, 1 $\mathrm{mM}$ DTT, $50 \mathrm{mM} \mathrm{KCl}$, containing one dissolved tablet of protease inhibitor cocktail Complete $^{\mathrm{TM}}$ Mini; from Roche) was adsorbed to a GSH-Sepharose column (1.5 ml; Amersham) equilibrated in the same buffer without protease inhibitors. The unbound proteins were washed out with $15 \mathrm{ml}$ of $50 \mathrm{mM}$ Tris-HCl, $\mathrm{pH}$ 7.5, $1 \mathrm{mM}$ EDTA, $1 \mathrm{mM}$ DTT, $150 \mathrm{mM} \mathrm{NaCl}$. ADPRibase-Mn was separated from the GST tag by in-column proteolysis with PreScission ${ }^{\mathrm{TM}}$ protease followed by elution with wash buffer. The eluted enzyme $(1.8 \mathrm{ml})$ was frozen at $-80^{\circ} \mathrm{C}$ in $50-\mu 1$ aliquots. This was a high-purity enzyme preparation (Figure S1, lane 6). Upon thawing, the enzyme was stable at least for one week. The expression and purification procedure was carried out three times with the same results. 
Native molecular weight of ADPRibase-Mn by gel filtration chromatography

Samples of ADPRibase-Mn and molecular weight markers were chromatographed in a Protein-Pak 125 column $(7.8 \mathrm{~mm}$ x $300 \mathrm{~mm})$ from Waters, equilibrated in $50 \mathrm{mM}$ Tris, pH 7.5, 1 mM EDTA, $150 \mathrm{mM} \mathrm{NaCl}$, and connected to a Hewlett-Packard HP1090 chromatograph. The elutions were performed with equilibrating buffer at $1 \mathrm{ml} / \mathrm{min}$ and the chromatographic profiles were recorded at $280 \mathrm{~nm}$. For ADPRibase-Mn activity assay, $0.25 \mathrm{ml}$ fractions were collected.

Enzyme activity assays

The hydrolytic activities of ADPRibase-Mn on NDP-X substrates were assayed at $37^{\circ} \mathrm{C}$ by coupling to alkaline phosphatase and measuring colorimetrically the amount of $\mathrm{P}_{\mathrm{i}}$ formed with a dodecyl sulphate-ascorbate-molybdate reagent [21]. The assay mixtures contained, except when otherwise stated, $50 \mathrm{mM}$ Tris- $\mathrm{HCl}\left(\mathrm{pH} 7.5\right.$ at $25^{\circ} \mathrm{C}$ ), $500 \mu \mathrm{M}$ NDP-X, $100 \mu \mathrm{M} \mathrm{MnCl}_{2}, 1.5 \mu \mathrm{g} / \mathrm{ml}$ (5.5 units/ml) alkaline phosphatase, and the appropriate amount of enzyme sample. For the assay of the chromatographic profiles of ADPRibase-I, ADPRibase-Mn and ADPRibase-II in fractionated rat tissue extracts, 1 $\mathrm{mg}$ bovine serum albumin $/ \mathrm{ml}$ was included in the reaction mixtures. Whenever the substrate was NDP or NMP, alkaline phosphatase was omitted. For the $\mathrm{pH}$-activity profiles, different buffers were used, $\mathrm{MnCl}_{2}$ was increased to $1 \mathrm{mM}$, and the concentration of alkaline phosphatase was doubled. In every case, the reaction was stopped and colour developed by addition of either $0.7 \mathrm{ml}$ of standard $\mathrm{P}_{\mathrm{i}}$ reagent to 0.05 $0.1 \mathrm{ml}$ or, when higher sensitivity was needed, $0.5 \mathrm{ml}$ of a concentrated reagent to 0.4 $\mathrm{ml}$ of reaction mixture. For studies of enzyme saturation, initial rates were measured at diverse substrate concentrations and the data were adjusted by non-linear regression to the Michaelis-Menten equation [24]. For inactivation studies with $o$-phenanthroline, the activity was assayed in standard reaction mixtures without alkaline phosphatase, by measuring the conversion of ADP-ribose to AMP by HPLC after 15 min of reaction. Enzyme activities were linear with time and amount of enzyme. Blanks without enzyme and/or substrate were run in parallel. One unit enzyme activity is defined as $1 \mu \mathrm{mol}$ substrate hydrolysed/min.

HPLC detection of NMP as reaction product of ADPRibase-Mn

Reaction mixtures with all the substrates hydrolysed by ADPRibase-Mn were analysed by ion-pair reverse-phase HPLC in a $15 \mathrm{~cm}$ x $0.4 \mathrm{~cm}$ octadecylsilica column (Kromasil 100, Teknokroma, Spain) with a $1 \mathrm{~cm} \times 0.4 \mathrm{~cm}$ pre-column of the same material, using a Hewlett-Packard HP1100 chromatograph. Two elution buffers were used: A, $5 \mathrm{mM}$ sodium phosphate, $\mathrm{pH} 7.0,20 \mathrm{mM}$ tetrabutylammonium and $10 \%$ (vol/vol) methanol; $\mathrm{B}$, same as A with $100 \mathrm{mM}$ sodium phosphate. Before each run, the column was equilibrated in buffer A. Samples of $20 \mu 1$ (reaction mixture) were injected, and the elution was accomplished at $1 \mathrm{ml} / \mathrm{min}$ with a linear, 10-min 5-100 $\mathrm{mM}$ phosphate gradient, followed by a 10 -min isocratic wash with buffer $\mathrm{B}$. The chromatograms were recorded at $260 \mathrm{~nm}$. The retention times of compounds relevant to the reactions catalysed by ADPRibase-Mn were (min): adenosine, 2.6; AMP, 6.6; ADP, 11.7; ADPribose, 8.5; cytidine, 1.5; CMP, 4.4; CDP, 7.7; CDP-ethanolamine, 2.3; CDP-choline, 2.2; CDP-glycerol, 5.0. This allowed the identification of either AMP or CMP as the nucleotide product of hydrolysis for every substrate of ADPRibase-Mn. 
Multiple tissue northern blot

A multiple rat tissue northern blot containing $2 \mu \mathrm{g}$ mRNA from each tissue, and prestained with Blot Stain Blue (Figure S2; Sigma), was used. The blot was probed with a digoxigenin-labeled cDNA containing the full ORF of rat ADPRibase-Mn. The labelling was performed with the DIG High Prime DNA Labeling kit (Roche) according to manufacturer instructions. Hybridisation and detection were performed by the optimized protocol described elsewhere [25] except that probe concentration was $10 \mathrm{ng}$ $\mathrm{cDNA} / \mathrm{ml}$, the hybridisation steps were carried out at $55^{\circ} \mathrm{C}$, and ready-to-use CSPD was the substrate for the chemiluminescent reaction catalysed by alkaline phosphataselabeled anti-digoxigenin (Roche). The results were recorded first by luminescent quantitative detection (Kodak Image Station 2000R) under conditions in which signal accumulation was linear with time and with the amount of labelled probe and, second, by exposure of X-ray film to the chemiluminescent blot.

Rat tissue or cell extract fractionation to assay ADPRibase-I, ADPRibase-Mn and ADPRibase-II

Female Wistar rats weighing 200-220 g, fed ad libitum, were provided by the Servicio de Animalario of the Universidad de Extremadura, Badajoz. The animals were killed by rapid decapitation and the organs of interest (liver, skeletal muscle, spleen and thymus) were immediately dissected. After washing in cold saline, the tissue was blotted dry and weighed. Depending on the organ, $0.35-1.3 \mathrm{~g}$ of tissue were processed.

The protocol to obtain rat splenocytes and to remove red blood cells was as described [26], except that spleens were crushed in $10 \mathrm{ml}$ of cold saline, the red cell lysing buffer was purchased from Roche, and the final washes of splenocytes were performed with $14.5 \mathrm{mM}$ Tris, $\mathrm{pH}$ 7.6, $5 \mu \mathrm{M} \mathrm{CaCl}_{2}, 98 \mu \mathrm{M} \mathrm{MgCl}_{2}, 0.54 \mathrm{mM} \mathrm{KCl}, 126$ $\mathrm{mM} \mathrm{NaCl}$, and $0.1 \mathrm{~g} / \mathrm{l}$ of glucose.

The separation of ADPRibase-I, ADPRibase-Mn and ADPRibase-II was carried out, with some simplification, as described [19]. The tissue samples were homogenised on ice, in buffer containing $50 \mathrm{mM}$ Tris, $\mathrm{pH}$ 7.5, $0.5 \mathrm{mM}$ EDTA, $1 \mathrm{mM}$ PMSF, using 6 $\mathrm{ml} / \mathrm{g}$ tissue (liver and muscle), $9 \mathrm{ml} / \mathrm{g}$ tissue (spleen and thymus), or $4.5 \mathrm{ml}$ per washed splenocyte pellet obtained from one spleen. A hand-driven Potter type was used, except for muscle that was homogenized first in a motor-driven blendor and then finished in the Potter. With every tissue, $4-5 \mathrm{ml}$ of homogenate was centrifuged for $60 \mathrm{~min}$ at $4^{\circ} \mathrm{C}$ and 33,000 rpm in a Beckman SW45 rotor. The supernatant was chromatographed in a Sephadex G-100 column ( $1 \mathrm{~cm} \times 90 \mathrm{~cm}$ ) equilibrated and eluted with $20 \mathrm{mM}$ Tris, $\mathrm{pH}$ $7.5,0.5 \mathrm{mM}$ EDTA at $20 \mathrm{ml} / \mathrm{h}$. Fractions of about $2.5 \mathrm{ml}$ were collected and the $\mathrm{Mg}^{2+}$ and the $\mathrm{Mn}^{2+}$-dependent ADP-ribose hydrolase activities were assayed. A small peak of activity eluting in the void volume was discarded, and the fractions of a large, included peak of ADP-ribose hydrolase, active with both $\mathrm{Mg}^{2+}$ or $\mathrm{Mn}^{2+}$, were pooled. This peak contained ADPRibase-I, ADPRibase-Mn and ADPRibase-II, and it was applied to a

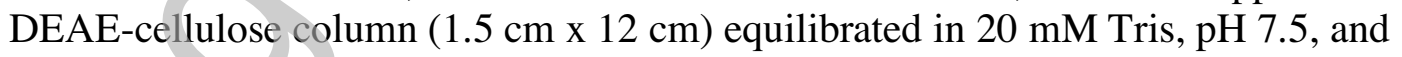
washed with 2-3 volumes of $20 \mathrm{mM}$ Tris, $\mathrm{pH} 7.5,0.5 \mathrm{mM}$ EDTA, $50 \mathrm{mM} \mathrm{KCl}$, followed by a $130-\mathrm{ml}$ linear gradient of $50-400 \mathrm{mM} \mathrm{KCl}$ in the same buffer. The three enzymes were resolved within the gradient, allowing their individual quantitation. A careful accounting was kept such that activities quantitated after the DEAE-cellulose step could be extrapolated back and referred to total tissue protein measured in the homogenate with bovine serum albumin as a standard [27]. 
Docking of ADP-ribose to the homology model of rat ADPRibase-Mn

The theoretical coordinates of rat ADPRibase-Mn were taken from the SwissProt Repository [28]. This homology model is based on the crystal structure of the zebrafish protein (pdb entry: $2 \mathrm{NXF}$ ), which contains two $\mathrm{Zn}^{2+}$ ions in a typical metallophosphoesterase dinuclear centre. Since there was an excellent structural similarity between the zebrafish and the rat proteins concerning the residues located within $5 \AA$ of the $\mathrm{Zn}^{2+}$ ions (RMSD $0.082 \AA$ ), the metal coordinates of the crystal structure were used to place them in the homology model. The protonation state of His side chains was assigned with the program Reduce [29]. Atom types and Kollman partial charges were assigned with AutoDockTools (ADT). The zinc ions were modelled with charge 2+ and default AutoDock 4 radius and well depth. ADP-ribose was prepared with Marvin 4.1.13, 2007, ChemAxon (http://www.chemaxon.com), its Gasteiger charges were calculated with ADT (total charge: 2-), and all its torsionable groups were made flexible except 6- $\mathrm{NH}_{2}$, and 2', 3', 2"' and 3" $-\mathrm{OH}$. Docking of ADPribose was run with AutoDock 4 [30] within a scoring grid (sized $33.8 \times 29.2 \times 29.2 \AA$ with a resolution of $0.375 \AA$ ) centred around the putative active-site. AutoDock was run with the Lamarckian genetic algorithm with default parameters except that: 100 independent runs were performed; the maximum number of energy evaluations per run was set to $5 \times 10^{7}$; and the step sizes were adjusted to $0.2 \AA$ for translations and $5^{\circ}$ for orientations and torsions.

\section{RESULTS}

Tandem-mass spectrometry of rat liver ADPRibase-Mn pointed to a hypothetical rat protein that was cloned and expressed

For identification, a peptide-mass fingerprint of the 38-kDa band of rat liver ADPRibase-Mn was obtained. In a Mascot search [31] against the NCBInr database, it did not give any significant candidate. Therefore, two peptides of $1746.88 \mathrm{Da}$ and 2126.98 Da were analysed by tandem mass spectrometry. Searches with these data pointed to two tryptic peptides formed by amino acids 47-61 (HSLVHLQGAIEDWNK) and 102-118 (VPVHHTWGNHEFYNFSR) of a 337 amino-acid hypothetical rat protein (accession No. AAH88174). Its theoretical mass of $38710 \mathrm{Da}$ agreed with the $38-\mathrm{kDa}$ protein band. It was recorced as a product of the rat gene RGD1309906 (GeneID 287406) which was annotated just as 'hydrolase'. The coding sequence (accession No. BC088174) of the hypothetical protein was used to design the PCR cloning described under Experimental.

Plasmid pGEX-6P-3-rADPRMn contained, in frame with a GST affinity label, the PCR-amplified, 1014-nt ORF coding for ADPRibase-Mn. Relative to the ORF used as reference, it displayed 3 nucleotide changes: G12A (due to the design of the forward PCR primer), A131G and A636G, only one causing an amino acid change (Y44C). This sequence was deposited in GenBank (accession No. EU037900).

The GST/ADPRibase-Mn fusion of theoretical $65080 \mathrm{Da}$ was expressed from pGEX-6P-3-rADPRMn as a $\approx 65-\mathrm{kDa}$ protein (Figure S1, lane 2), and it was adsorbed to GSH-Sepharose. The ADPRibase-Mn moiety was recovered by in-column proteolysis as a $\approx 40-\mathrm{kDa}$ protein (Figure S1, lane 6). This agrees with an expected mass of 39360 Da, sum of ADPRibase-Mn and the N-terminal extension (GPLGSPNS) left by proteolysis. 
Characterisation of the recombinant protein as a $\mathrm{Mn}^{2+}$-dependent ADP-ribose/CDPalcohol pyrophosphatase identical to ADPRibase-Mn

Like rat liver ADPRibase-Mn [19], the recombinant enzyme hydrolysed ADP-ribose and CDP-alcohols. At $500 \mu \mathrm{M}$ substrate and $100 \mu \mathrm{M} \mathrm{MnCl}_{2}, \mathrm{CDP}$-choline gave the highest rate, followed by CDP-glycerol, CDP-ethanolamine, ADP-ribose and ADP (Table 1). However, kinetic parameters derived from hyperbolic saturation curves (Figure S3) showed ADP-ribose as the best substrate $\left(k_{\text {cat }} / K_{\mathrm{m}}=328000 \mathrm{M}^{-1} \mathrm{~s}^{-1}\right)$, whereas CDP-alcohols and ADP were hydrolysed with 3.5-15 fold lower efficiencies (Table 1). ADP-glucose, UDP-glucose, CDP-glucose, CDP, CMP and AMP were not hydrolysed.

All the reactions involved the hydrolysis of the phosphoanhydride linkage, as: (i) $\mathrm{P}_{\mathrm{i}}$ was formed by alkaline phosphatase from the NDP-X reaction products but not from the substrates; (ii) $\mathrm{P}_{\mathrm{i}}$ was directly formed from ADP; (iii) AMP or CMP were identified as products by HPLC (results not shown).

ADPRibase-Mn was inactive without added $\mathrm{Mn}^{2+}$ and showed high affinity for it, since saturation was observed at low micromolar $\mathrm{Mn}^{2+}$, well below the $500 \mu \mathrm{M}$ substrate concentration (Figure S3). The concentration of $\mathrm{MnCl}_{2}$ giving the halfmaximal rate was $1-4 \mu \mathrm{M}$. In no case, $\mathrm{Mg}^{2+}$ substituted for $\mathrm{Mn}^{2+}$.

Incubation with $2.5 \mathrm{mM}$ EDTA did not affect ADPRibase-Mn activity. This was in agreement with the stability of the enzyme frozen for months in a buffer with $1 \mathrm{mM}$ EDTA. However, $o$-phenanthroline caused near full inactivation in $1.5 \mathrm{~h}$ (Figure 1).

The effect of $\mathrm{pH}$ on ADPRibase-Mn activities was studied in the range of $\mathrm{pH} 6-$ 10. The profile of ADP-ribose hydrolase showed an optimum at $\mathrm{pH} 8.0-8.5$, whereas the activities on ADP and CDP-alcohols were highest at $\mathrm{pH} 6-8$, and decreased abruptly at higher $\mathrm{pH}$ (Figure 2).

ADPRibase-Mn behaved as a monomer, with an apparent mass of $\approx 30 \mathrm{kDa}$ by gel filtration (Figure S4), in good agreement with the native mass of $32 \mathrm{kDa}$ observed for the enzyme purified from rat liver [19].

Characterisation of ADPRibase-Mn as a protein belonging to the metallophosphoesterase, not to the Nudix superfamily

In contrast to other ADP-ribose pyrophophatases, ADPRibase-Mn lacked the amino acid signature of the Nudix superfamily. Searches in the InterPro site (http://www.ebi.ac.uk/InterProScan) and Superfamily database (http://supfam.org/SUPERFAMILY) identified a metallophosphoesterase domain (IPR004843), indicating that ADPRibase-Mn belongs to the Pfam metallophos family (accession ID PF00149), and is a member of the Scop metallo-dependent phosphatase superfamily (accession ID SSF56300). These proteins contain (1) a dimetal centre with diverse ion pairs or combinations, (2) a $\beta \alpha \beta \alpha \beta$ secondary structure signature within (3) a four-layered fold with two $\beta$-sheets flanked by $\alpha$-helices $(\alpha / \beta / \beta / \alpha$ fold), and (4) a disperse sequence signature that includes, in five conserved regions, the amino acids coordinated with the metal ions: DX[H/X]-(X)n-GDXX[D/X]-(X)n-GNH[D/E]-(X)n$[\mathrm{G} / \mathrm{X}] \mathrm{H}-(\mathrm{X}) \mathrm{n}-\mathrm{GHX}[\mathrm{H} / \mathrm{X}]$ [32-35]. The aligment of ADPRibase-Mn orthologues found by BlastP searches (Table 2) revealed these five regions (Figure 3, I-V).

The crystal structure of the zebrafish (Danio rerio) orthologue complexed with $\mathrm{P}_{\mathrm{i}}$ and two $\mathrm{Zn}^{2+}$ ions [36], and a homology model of the rat protein [28] were found in public databases. They display the $\alpha / \beta / \beta / \alpha$ metallophosphoesterase fold, with the five regions of the sequence signature brought together each at the $C$-end of a different $\beta$ strand: regions I-III belong to one of the $\beta$-sheets, and regions IV-V to the other. Seven of the conserved amino acids, which show an excellent structural similarity between the zebrafish and the rat proteins, form a dimetal centre located at the bottom of a groove. 
ADP-ribose was succesfully docked to the rat protein model into this site, indicating that it can be the active centre (Figure 4A,B). The amino acids that form the dimetallic centre and/or might interact with the substrate are shown in Figure 4C.

The gene encoding ADPRibase-Mn in Rattus norvegicus and mammalian orthologues

A BlastN query to the $R$. norvegicus genome using the ORF sequence of rat ADPRibase-Mn revealed that the gene RGD1309906 (GeneID 287406; also known as MDSO06 and MGC108803) is the only significantly related locus. It is a predicted gene located in rat chromosome 10 (10q24) that contains five exons, of which only the three last ones are translated and were hit by the BlastN search. The ADPRibase-Mn ORF spans from the $5^{\prime}$-end of exon 3 to within exon 5 (Figure 5). The reference rat genome contains the coding sequence of hypothetical protein LOC287406 (accession No.

BC088174), identical to that coding for recombinant ADPRibase-Mn except for the nucleotide differences mentioned above. Figure 5 shows also the organisation of the mouse and human genes and the ORFs coding for ADPRibase-Mn orthologues in these organisms. TBlastN and BlastN searches pointed to an inverse $427-\mathrm{pb}$ repetition including most of exon 5 and located $130 \mathrm{~kb}$ downstream of the rat gene, a feature not observed in the mouse or human genomes.

In human, mouse and rat, in addition to ADPRibase-Mn orthologues of 337-342 amino acids (Figure 3), BlastP searches found shorter protein variants due to an alternative $5^{\prime}$-splice site of the intron following the first translated exon. They were either conceptual translations from alternatively spliced transcripts (e.g. accession Nos BC001294 and BC070155 for human, and AK009142 for mouse mRNAs) or genomic predictions (accession number EDL10423 for mouse and EDM04778 for rat proteins). The alternative $5^{\prime}$-splice leaves 86-nt of the intron $5^{\prime}$-end attached to the preceding exon after splicing (Figure 5). The alternative transcription pattern contains an in-frame stop codon either within the retained intron segment (human and mouse) or in the next exon (rat). By the time of submitting this article, some databases point to the shorter version of the protein as the gene product.

\section{Restricted taxonomic distribution of ADPRibase-Mn orthologues}

Orthologous genes of RGD1309906 are recorded only among vertebrates, higher plants and algae. As this seemed an important phylogenetic feature, we run BlastP and TBlastN searches that found ADPRibase-Mn orthologous in those phyla, but not in invertebrates and fungi (Table 2). In the latter cases, TBlastN searches of complete genomes, confirmed that the absence of orthologous proteins was not due just to their not being recorded yet.

ADPRibase-Mn gene expression: differential expression in immune and non-immune rodent tissues

Upon inspection of the Gene Expression Omnibus (GEO) database for ADPRibase-Mnrelated genes, a genomics-based investigation aimed to identify mouse immune-genes came to our attention (GEO dataset GDS2068 [37]). Out of the 8734 genomic features explored in this microarray experiment, 360 show preferential expression in thymus, spleen, peripheral blood mononuclear cells, lymph nodes (unstimulated or stimulated), or in vitro activated T-cells. These features were linked to 333 unique genes, one of them being 2310004I24Rik, the orthologue of ADPRibase-Mn. The probe representing this gene in the microarray is a cDNA of the alternatively spliced mRNA (AK009142) that encodes the short protein variant (see above and Figure 5). It is likely to hybridize 
with both types of transcripts as they differ only in a 86-nt insert within a length of $\approx 1500 \mathrm{nt}$. The expression profile of 2310004I24Rik is shown in Figure S5, together with the heat plot of its profile neighbours (listed in Table 3 with their assigned functions [37]). To confirm the preferential expression of ADPRibase-Mn in rodent immune tissues, the UniGene database was inspected, and a northern blot analysis and a fractionation study of the ADP-ribose pyrophosphatases in soluble extracts of selected rat tissues were run.

Using the UniGene's EST Profile Viewer to analyse mouse ESTs, one can see that ADPRibase-Mn is most strongly expressed in thymus (Table S1). Expression in spleen is also observed but not as prominently as in the microarray.

The northern blot was hybridised with a rat cDNA probe that revealed a major transcript of $\approx 1.4 \mathrm{~kb}$ in all tissues analysed (Figure 6), in agreement with the structure of $R G D 1309906$ gene (Figure 5). Longer transcripts of $\approx 3 \mathrm{~kb}$ and $\approx 5 \mathrm{~kb}$ were also observed in some tissues. Quantitation of the RNA signals indicated higher expression in thymus and spleen than in the other rat tissues.

As stated in the Introduction, besides ADPRibase-Mn, rat liver supernatants contain other two ADP-ribose pyrophosphatases, named ADRibase-I and ADPRibaseII, which work with either $\mathrm{Mg}^{2+}$ or $\mathrm{Mn}^{2+}$ as the activating cation [19]. To distinguish the ADP-ribose pyrophosphatase activity of ADPRibase-Mn from the other hydrolases, fractionation of tissue supernatants was necessary (Figure S6). This allowed the quantitation of the three enzymes in five different rat sources: thymus, spleen, splenocytes, liver and skeletal muscle (Table 4). ADPRibase-Mn activity in thymus and spleen was 2.5-5-fold higher than in liver and muscle. The ratio was even higher when ADPRibase-Mn was quantitated in splenocytes, where the activity was 4-8-fold higher than in the non-immune tissues (Table 4).

\section{DISCUSSION}

Our results provide a molecular identity for ADPRibase-Mn and a biochemical basis for the functional annotation of the rat gene RGD1309906, likely extrapolable to other mammalian genes coding for strongly similar hypothetical metallophosphoesterases. This includes the mouse gene 2310004I24Rik and the human gene $c 17$ orf48, which respectively encode proteins $95 \%$ and $85 \%$ identical to rat ADPRibase-Mn.

Not every known NDP-X hydrolase is a member of the Nudix superfamily [38, 39] but, in fact, all those with a clear or relative preference for ADP-ribose [13-15, 22, 40, 41] or CDP-alcohol [41, 42] are. It has been pointed out that the $\mathrm{Mn}^{2+}$-dependent Nudix hydrolase YZGD, from Paenibacillus thiaminolyticus, displays a specificity similar to ADPRibase-Mn [41]. Therefore, that the latter is a metallophosphoesterase was relatively unexpected. In the Scop classification, the metallo-dependent phosphatase superfamily is currently divided in several families, including: purple acid phosphatase; DNA double-strand break repair nuclease; 5'nucleotidase (syn. UDPsugar hydrolase), N-terminal domain; protein serine/threonine phosphatase; and others. Searches in the Superfamily server (http://supfam.org/SUPERFAMILY) failed to asign ADPRibase-Mn to any established Scop family (no E-value $<0.01$ was obtained), suggesting that it may constitute a novel protein family that can be provisionally described as ADP-ribose/CDP-alcohol pyrophosphatase.

ADPRibase-Mn is inactive in the absence of added metals, and is activated by low micromolar concentrations of $\mathrm{Mn}^{2+}$, but not of $\mathrm{Mg}^{2+}$. Activation by $\mathrm{Mn}^{2+}$ reflects metal binding to the enzyme, not just to the free substrate, as half saturation was obtained at 1$4 \mu \mathrm{M} \mathrm{MnCl}_{2},>100$ fold lower than the substrate. This is compatible with $\mathrm{Mn}^{2+}$ being a 
natural activator of the enzyme, as free $\mathrm{Mn}^{2+}$ is estimated to be $0.7 \mu \mathrm{M}$ in hepatocytes from fed rats and $0.25 \mu \mathrm{M}$ in hepatocytes from fasted rats [43].

The metal centre of metallophosphoesterases can contain a couple of the same or different metals in varying combinations. However, it is unclear whether activation by $\mathrm{Mn}^{2+}$ reflects binding to the dinuclear centre or otherwise. In fact, the structure of the zebrafish orthologue of ADPRibase-Mn was determined with two $\mathrm{Zn}^{2+}$ ions in the dinuclear centre, but it also contained two $\mathrm{Zn}^{2+}$ ions at other locations [36]. The timedependent inactivation of rat ADPRibase-Mn by phenanthroline, not by EDTA, could indicate that a metal different from $\mathrm{Mn}^{2+}$ could be part of the enzyme, perhaps $\mathrm{Fe}$ or $\mathrm{Zn}$, that form more stable complexes with the former chelator. However, phenanthroline could also be acting as an inhibitor by binding to the active centre. In summary, further evidence is needed to elucidate the nature of the metals bound to ADPRibase-Mn and their structural and/or functional role.

The putative active centre of ADPRibase-Mn is in the groove where $\mathrm{P}_{\mathrm{i}}$ lies bound to the $\mathrm{Zn}^{2+}$ ions of the crystal structure of the zebrafish protein [36]. In the homology model of the rat protein, a docked ADP-ribose fits into that groove, with the $\beta$ phosphate of ADP occupying a position similar to $\mathrm{P}_{\mathrm{i}}$ in the $\mathrm{X}$-ray structure. All the ADP-ribose interactions with the $\mathrm{Zn}^{2+}$ ions, and most of those established with the protein, involve the pyrophosphate group (Figure 4 and legend), and it is likely that some of them are important for catalysis. For instance, His111 (part of the conserved GNHE region III in Figure 3) interacts with the oxygen of the phosphoanhydride linkage hydrolysed by ADPRibase-Mn, as in other metallophosphoesterases where this interaction is catalytically relevant [44]. On the other hand, the specificity of ADPRibase-Mn for NDP(-X) compounds (Table 1) should be accounted for by interactions of the $\mathrm{N}$ and the $\mathrm{X}$ portions of the substrate. In the ADP-ribose docking model, while the pyrophosphate group is in a rather closed environment, adenine and the distal ribose protrude towards more open areas of the protein surface (Figure 4B). On the N side of ADP-ribose, a hydrophobic contact of adenine with Leu196 is observed, but not any hydrogen bond. On the X side, two possible interactions of the 1"-OH group with backbone atoms of His278 and His280, and a favorable contact of the ribose ring with Cys253 are observed. It is unclear whether these interactions alone account for the preferences of ADPRibase-Mn for ADP versus CDP, for NDP-X versus the corresponding NDPs, and for ADP-ribose versus ADP-glucose as summarized in Table 1. Anyhow, it must be stressed that the theoretical structure of rat ADPRibase-Mn is derived by homology to a zebrafish protein complexed with $\mathrm{P}_{\mathrm{i}}$, a ligand much smaller than ADP-ribose. In a tue enzyme-substrate complex, specific interactions may depend on an induced fit of the enzyme which $\mathrm{P}_{\mathrm{i}}$ would not possibly evoke.

ADPRibase-Mn may have a function in vertebrate immune systems. Mining of expression databases identified a mouse microarray experiment in which gene

2310004I24Rik, that codes for the mouse orthologue of ADPRibase-Mn, is labeled as an 'immune gene', preferentially expressed in immune versus non-immune cells and tissues [37]. As a complement to this, rat ADPRibase-Mn mRNAs were found more abundant (Figure 6) and enzyme activity was higher (Table 4) in thymus and spleen than in nonimmune rat tissues. ADPRibase-Mn activity was even higher in splenocytes, that include spleen immunocytes (Table 4). Such a pattern was not observed for the Nudixtype ADPRibase-I (Nudt9) and ADPRibase-II (Nudt5), either when assaying enzyme activities in rat tissues (Table 4) or in the RNA expression of the mouse orthologue of the rat $N u d t 5$ gene that codes for ADPRibase-II (a probe for the Nudt9 orthologue, that codes for ADPRibase-I, was not included in the microarray [37]). Also in agreement with a role in the vertebrate immune system, a restriction was found in the taxonomic distribution of ADPRibase-Mn orthologues. BlastP and TblastN searches revealed they occur in all vertebrates with the possible exception of birds, but not in invertebrates and 
most lower eukaryots (Table 2). This contrasts, e.g., with genes orthologous to Nudt9 (coding for ADPRibase-I) which, besides in vertebrates, is represented in Drosophila and C. elegans [14], or to Nudt5 (coding for ADPRibase-II), which is represented in $C$. elegans and Saccharomyces [22]. The immune role of ADPRibase-Mn is unknown. In the above-mentioned microarray study [37], a cellular function was assigned to 298 of the 333 mouse immune genes identified, grouped in about 20 functional sets labeled as e.g. defense, apoptosis, immune, signaling, metabolism, etc (see e.g. Table 3). Immunegene 2310004I24Rik, here shown to code for the mouse orthologue of ADPRibase-Mn, was annotated just as metallophosphoesterase, and could not be assigned to either of those functional sets [37]. The role of ADP-ribose as a second messenger of stress in immune cells $[9,10,45-47]$ points to a signaling role for ADPRibase-Mn. This agrees with the roles of the immune genes that are profile neighbours of 2310004I24Rik in the microarray study. While $16 \%$ of the 298 immune genes with a known role are marked 'signaling' [37], this increases to $43 \%$ among the profile neighbours of 2310004I24Rik (Table 3). ADPRibase-Mn in the immune system could be related to ADP-ribose turnover and to the termination of its effects on TRPM2 channels. Since the immunegene microarray does not contain a TRPM2 probe, to compare 2310004I24Rik and TRPM2 expression in mouse tissues, we inspected the UniGene database using the EST Profile Viewer. Both genes are expressed at low levels (e.g. as compared with $\beta$-actin), what makes comparisons difficult in terms of numbers of ESTs counted. Anyhow, considering only body sites for which a high number of total ESTs is on record (> 40000), one can see that TRPM2 expression is accompannied by ADPRibase-Mn. This represents only a partial correlation, because several sites express ADPRibase-Mn but not TRPM2 (Table S1).

CDP-choline and CDP-ethanolamine are key intermediates in biosynthetic pathways of, respectively, phosphatidylcholine and phosphatidylethanolamine [48, 49]. The formation of CDP-choline by CTP-phosphocholine cytidylyltransferase is ratelimiting and important for the regulation of phosphatidylcholine biosynthesis. ADPRibase-Mn is the only mammalian NDP-X hydrolase showing a relative preference for CDP-choline (Table 1). Working simultaneously with the cytidylyltransferase, ADPRibase-Mn would form a futile substrate cycle that could contribute also to regulation:

(cytidylyltransferase) $\mathrm{CTP}+$ phosphocholine $\rightarrow \mathrm{CDP}$-choline $+\mathrm{PP}_{\mathrm{i}}$

$$
\text { (ADPRibase-Mn) CDP-choline }+\mathrm{H}_{2} \mathrm{O} \rightarrow \mathrm{CMP}+\text { phosphocholine }
$$

A similar reasoning can be applied to the CDP-etanolamine pathway. In conclusion, a role of ADPRibase-Mn related to its CDP-alcohol substrates, cannot be discarded.

\section{ACKNOWLEDGMENTS}

We are grateful to Antonio Sillero and María Antonia Günther for their generous support of this research. JRR is indebted to the Escola Superior de Tecnologia e Gestão, Instituto Politécnico de Leiria, Portugal, for permission to be on leave. Thanks are due to the Ministerio de Educación y Ciencia, Spain, for Grant BFU2006-00510, cofinanced by FEDER, to the Consejería de Infraestructuras y Desarrollo Tecnológico, Junta de Extremadura Spain, for Grants GRU06031 and GRU07066, cofinanced by FSE and FEDER, and to the Vicerrectorado de Investigación, Desarrollo e Innovación, Universidad de Extremadura, for Grant A7-09. 


\section{REFERENCES}

1 Hilz, H. (1997) ADP-ribose. A historical overview. Adv. Exp. Med. Biol. 419, 15-24

2 Berger, F., Ramirez-Hernandez, M. H. and Ziegler, M. (2004) The new life of a centenarian: signalling functions of NAD(P). Trends Biochem. Sci. 29, 111-118

3 Jacobson, E. L., Cervantes-Laurean, D. and Jacobson, M. K. (1997) ADP-ribose in glycation and glycoxidation reactions. Adv. Exp. Med. Biol. 419, 371-379

4 Just, I., Wollenberg, P., Moss, J. and Aktories, K. (1994) Cysteine-specific ADP-ribosylation of actin. Eur. J. Biochem. 221, 1047-1054

5 Wondrak, G. T., Cervantes-Laurean, D., Jacobson, E. L. and Jacobson, M. K. (2000) Histone carbonylation in vivo and in vitro. Biochem. J. 351, 769-777

6 Perraud, A. L., Fleig, A., Dunn, C. A., Bagley, L. A., Launay, P., Schmitz, C., Stokes, A. J., Zhu, Q., Bessman, M. J., Penner, R., Kinet, J. P. and Scharenberg, A. M. (2001) ADP-ribose gating of the calcium-permeable LTRPC2 channel revealed by Nudix motif homology. Nature 411, 595-599

7 Sano, Y., Inamura, K., Miyake, A., Mochizuki, S., Yokoi, H., Matsushime, H. and Furuichi, K. (2001) Immunocyte $\mathrm{Ca}^{2+}$ influx system mediated by LTRPC2. Science 293, 1327-1330

8 Gerth, A., Nieber, K., Oppenheimer, N. J. and Hauschildt, S. (2004)

Extracellular NAD ${ }^{+}$regulates intracellular free calcium concentration in human monocytes. Biochem. J. 382, 849-856

9 Kühn, F. J., Heiner, I. and Lückhoff, A. (2005) TRPM2: a calcium influx pathway regulated by oxidative stress and the novel second messenger ADPribose. Pflugers Arch. 451, 212-219

10 Perraud, A. L., Takanishi, C. L., Shen, B., Kang, S., Smith, M. K., Schmitz, C., Knowles, H. M., Ferraris, D., Li, W., Zhang, J., Stoddard, B. L. and Scharenberg, A. M. (2005) Accumulation of free ADP-ribose from mitochondria mediates oxidative stress-induced gating of TRPM2 cation channels. J. Biol. Chem. 280, 6138-6148

11 Gasser, A., Glassmeier, G., Fliegert, R., Langhorst, M. F., Meinke, S., Hein, D., Krüger, S., Weber, K., Heiner, I., Oppenheimer, N., Schwarz, J. R. and Guse, A. H. (2006) Activation of T cell calcium influx by the second messenger ADPribose. J. Biol. Chem. 281, 2489-2496

12 Miró, A., Costas, M. J., García-Díaz, M., Hernández, M. T. and Cameselle, J. C. (1989) A specific, low $K_{\mathrm{m}}$ ADP-ribose pyrophosphatase from rat liver. FEBS Lett. 244, 123-126

13 Lin, S., Gasmi, L., Xie, Y., Ying, K., Gu, S., Wang, Z., Jin, H., Chao, Y., Wu, C., Zhou, Z., Tang, R., Mao, Y. and McLennan, A. G. (2002) Cloning, expression and characterisation of a human Nudix hydrolase specific for adenosine 5'-diphosphoribose (ADP-ribose). Biochim. Biophys. Acta 1594, 127135

14 Perraud, A. L., Shen, B., Dunn, C. A., Rippe, K., Smith, M. K., Bessman, M. J., Stoddard, B. L. and Scharenberg, A. M. (2003) NUDT9, a member of the Nudix hydrolase family, is an evolutionarily conserved mitochondrial ADP-ribose pyrophosphatase. J. Biol. Chem. 278, 1794-1801

15 Carloto, A., Costas, M. J., Cameselle, J. C., McLennan, A. G. and Ribeiro, J. M. (2006) The specific, submicromolar $K_{\mathrm{m}}$ ADP-ribose pyrophosphatase purified from human placenta is enzymically indistinguishable from recombinant NUDT9 protein, including a selectivity for $\mathrm{Mn}^{2+}$ as activating cation and increase in $K_{\mathrm{m}}$ for ADP-ribose, both elicited by $\mathrm{H}_{2} \mathrm{O}_{2}$. Biochim. Biophys. Acta 1760, 1545-1551 
16 Bessman, M. J., Frick, D. N. and O'Handley, S. F. (1996) The MutT proteins or "Nudix" hydrolases, a family of versatile, widely distributed, "housecleaning" enzymes. J. Biol. Chem. 271, 25059-25062

17 McLennan, A. G. (2006) The Nudix hydrolase superfamily. Cell. Mol. Life Sci. 63, 123-143

18 Cameselle, J. C., Costas, M. J., Günther Sillero, M. A. and Sillero, A. (1984) Two low $K_{\mathrm{m}}$ hydrolytic activities on dinucleoside 5 ', $5^{\prime \prime}-\mathrm{P}^{1}, \mathrm{P}^{4}$-tetraphosphates in rat liver. Characterization as the specific dinucleoside tetraphosphatase and a phosphodiesterase I-like enzyme. J. Biol. Chem. 259, 2879-2885

19 Canales, J., Pinto, R. M., Costas, M. J., Hernández, M. T., Miró, A., Bernet, D., Fernández, A. and Cameselle, J. C. (1995) Rat liver nucleoside diphosphosugar or diphosphoalcohol pyrophosphatases different from nucleotide pyrophosphatase or phosphodiesterase I: substrate specificities of $\mathrm{Mg}^{2+}$-and/or $\mathrm{Mn}^{2+}$-dependent hydrolases acting on ADP-ribose. Biochim. Biophys. Acta 1246, 167-177

20 Bernet, D., Pinto, R. M., Costas, M. J., Canales, J. and Cameselle, J. C. (1994) Rat liver mitochondrial ADP-ribose pyrophosphatase in the matrix space with low $K_{\mathrm{m}}$ for free ADP-ribose. Biochem. J. 299, 679-682

21 Ribeiro, J. M., Carloto, A., Costas, M. J. and Cameselle, J. C. (2001) Human placenta hydrolases active on free ADP-ribose: an ADP-sugar pyrophosphatase and a specific ADP-ribose pyrophosphatase. Biochim. Biophys. Acta 1526, 8694

22 Gasmi, L., Cartwright, J. L. and McLennan, A. G. (1999) Cloning, expression and characterization of YSA1H, a human adenosine 5'-diphosphosugar pyrophosphatase possessing a MutT motif. Biochem. J. 344, 331-337

23 Cabezas, A., Costas, M. J., Pinto, R. M., Couto, A. and Cameselle, J. C. (2005) Identification of human and rat FAD-AMP lyase (cyclic FMN forming) as ATPdependent dihydroxyacetone kinases. Biochem. Biophys. Res. Commun. 338, 1682-1689

24 Cleland, W. W. (1967) The statistical analysis of enzyme kinetic data. Adv. Enzymol. Relat. Areas Mol. Biol. 29, 1-32

25 Engler-Blum, G., Meier, M., Frank, J. and Muller, G. A. (1993) Reduction of background problems in nonradioactive northern and Southern blot analyses enables higher sensitivity than 32P-based hybridizations. Anal. Biochem. 210, 235-244

26 Kruisbeek, A. M. (2000) Isolation and fractionation of mononuclear cell populations. In Current Protocols in Immunology (Coligan, J. E., Bierer, B. E., Margulies, D. H., Shevach, E. M. and Strober, W., eds.), pp. 3.1.1-3.1.5, John Wiley \& Sons

27 Lowry, O. H., Rosebrough, N. J., Farr, A. L. and Randall, R. J. (1951) Protein measurement with the Folin phenol reagent. J. Biol. Chem. 193, 265-275

28 Kopp, J., Schwede, T. (2007) UniProt AC Q5M886, model for similar to RIKEN cDNA 2310004I24 gene from Rattus norvegicus (rat). http://swissmodel.expasy.org/repository/smr.php?sptr_ac=q5m886.

29 Word, J. M., Lovell, S. C., Richardson, J. S. and Richardson, D. C. (1999) Asparagine and glutamine: using hydrogen atom contacts in the choice of sidechain amide orientation. J. Mol. Biol. 285, 1735-1747

Morris, G. M., Goodsell, D. S., Halliday, R. S., Huey, R., Hart, W. E., Belew, R. K. and Olson, A. J. (1998) Automated docking using a Lamarckian genetic algorithm and an empirical binding free energy function. J. Comput. Chem. 19, $1639-1662$ 
31 Perkins, D. N., Pappin, D. J., Creasy, D. M. and Cottrell, J. S. (1999) Probability-based protein identification by searching sequence databases using mass spectrometry data. Electrophoresis 20, 3551-3567

32 Lohse, D. L., Denu, J. M. and Dixon, J. E. (1995) Insights derived from the structures of the Ser/Thr phosphatases calcineurin and protein phosphatase 1 . Structure 3, 987-990

33 Klabunde, T., Strater, N., Frohlich, R., Witzel, H. and Krebs, B. (1996) Mechanism of $\mathrm{Fe}(\mathrm{III}) \mathrm{Zn}$ (II) purple acid phosphatase based on crystal structures. J. Mol. Biol. 259, 737-748

34 Richter, W. (2002) 3',5' Cyclic nucleotide phosphodiesterases class III: members, structure, and catalytic mechanism. Proteins 46, 278-286

35 Shenoy, A. R., Capuder, M., Draskovic, P., Lamba, D., Visweswariah, S. S. and Podobnik, M. (2007) Structural and biochemical analysis of the Rv0805 cyclic nucleotide phosphodiesterase from Mycobacterium tuberculosis. J. Mol. Biol. 365, 211-225

36 Bitto, E., Wesenberg, G.E., Phillips Jr., G.N., McCoy, J.G., Bingman, C.A. (2006) Crystal structure of a dimetal phosphatase from Danio rerio LOC 393393. http://www.rcsb.org/pdb/explore.do?structureId=2NXF.

37 Hutton, J. J., Jegga, A. G., Kong, S., Gupta, A., Ebert, C., Williams, S., Katz, J. D. and Aronow, B. J. (2004) Microarray and comparative genomics-based identification of genes and gene regulatory regions of the mouse immune system. BMC Genomics 5, 82

38 Stefan, C., Jansen, S. and Bollen, M. (2005) NPP-type ectophosphodiesterases: unity in diversity. Trends Biochem. Sci. 30, 542-550

39 Galperin, M. Y., Moroz, O. V., Wilson, K. S. and Murzin, A. G. (2006) House cleaning, a part of good housekeeping. Mol. Microbiol. 59, 5-19

40 Yagi, T., Baroja-Fernández, E., Yamamoto, R., Muñoz, F. J., Akazawa, T., Hong, K. S. and Pozueta-Romero, J. (2003) Cloning, expression and characterization of a mammalian Nudix hydrolase-like enzyme that cleaves the pyrophosphate bond of UDP-glucose. Biochem. J. 370, 409-415

41 Tirrell, I. M., Wall, J. L., Daley, C. J., Denial, S. J., Tennis, F. G., Galens, K. G. and O'Handley, S. F. (2006) YZGD from Paenibacillus thiaminolyticus, a pyridoxal phosphatase of the HAD (haloacid dehalogenase) superfamily and a versatile member of the Nudix (nucleoside diphosphate $\mathrm{x}$ ) hydrolase superfamily. Biochem. J. 394, 665-674

42 Xu, W., Dunn, C. A., Jones, C. R., D'Souza, G. and Bessman, M. J. (2004) The 26 Nudix hydrolases of Bacillus cereus, a close relative of Bacillus anthracis. J. Biol. Chem. 279, 24861-24865

43 Ash, D. E. and Schramm, V. L. (1982) Determination of free and bound manganese(II) in hepatocytes from fed and fasted rats. J. Biol. Chem. 257, 92619264

44 Mitic, N., Smith, S. J., Neves, A., Guddat, L. W., Gahan, L. R. and Schenk, G. (2006) The catalytic mechanisms of binuclear metallohydrolases. Chem. Rev. 106, 3338-3363

45 Vu, C. Q., Coyle, D. L., Tai, H. H., Jacobson, E. L. and Jacobson, M. K. (1997) Intramolecular ADP-ribose transfer reactions and calcium signalling. Potential role of 2'-phospho-cyclic ADP-ribose in oxidative stress. Adv. Exp. Med. Biol. 419, 381-388

46 Fonfria, E., Marshall, I. C., Benham, C. D., Boyfield, I., Brown, J. D., Hill, K., Hughes, J. P., Skaper, S. D. and McNulty, S. (2004) TRPM2 channel opening in response to oxidative stress is dependent on activation of poly(ADP-ribose) polymerase. Br. J. Pharmacol. 143, 186-192 
47 Naziroglu, M. (2007) New molecular mechanisms on the activation of TRPM2 channels by oxidative stress and ADP-Ribose. Neurochem. Res. 32, 1990-2001

48 Vance, J. E. and Vance, D. E. (2004) Phospholipid biosynthesis in mammalian cells. Biochem. Cell Biol. 82, 113-128

49 Kent, C. (2005) Regulatory enzymes of phosphatidylcholine biosynthesis: a personal perspective. Biochim. Biophys. Acta 1733, 53-66

50 Bradford, M. M. (1976) A rapid and sensitive method for the quantitation of microgram quantities of protein utilizing the principle of protein-dye binding. Anal. Biochem. 72, 248-254 
Table 1 Substrate specificity and kinetic parameters of ADP-ribose/CDP-alcohol pyrophosphatase

\begin{tabular}{|c|c|c|c|c|c|}
\hline \multirow{3}{*}{ Substrate ${ }^{a}$} & \multirow{3}{*}{$\begin{array}{c}\begin{array}{c}\text { Enzyme } \\
\text { purified } \\
\text { from rat } \\
\text { liver }\end{array} \\
\text { Activity at } \\
500 \mu \mathrm{M} \\
\text { substrate } \\
(\%)\end{array}$} & \multicolumn{4}{|c|}{$\begin{array}{l}\text { Enzyme expressed from cloned DNA } \\
\text { (this work) }\end{array}$} \\
\hline & & \multirow{2}{*}{$\begin{array}{c}\text { Activity at } \\
500 \mu \mathrm{M} \\
\text { substrate }^{\mathrm{c}} \\
(\%)\end{array}$} & \multirow{2}{*}{$\begin{array}{c}k_{\text {cat }}{ }^{\mathrm{d}} \\
\mathrm{s}^{-1}\end{array}$} & \multirow{2}{*}{$\begin{array}{l}K_{\mathrm{m}}^{\mathrm{d}} \\
\mu \mathrm{M}\end{array}$} & \multirow{2}{*}{$\begin{array}{l}k_{\text {cat }} / K_{\mathrm{m}} \\
\mathrm{M}^{-1} \mathrm{~s}^{-1}\end{array}$} \\
\hline & & & & & \\
\hline ADP-ribose & 100 & $100 \pm 8$ & $12.8 \pm 0.2$ & $9 \pm 2$ & 328200 \\
\hline CDP-choline & 140 & $156 \pm 23$ & $28.5 \pm 0.6$ & $300 \pm 22$ & 95000 \\
\hline CDP-ethanolamine & 89 & $84 \pm 18$ & $41.3 \pm 1.1$ & $422 \pm 99$ & 29000 \\
\hline CDP-glycerol & 89 & $103 \pm 10$ & $28.1 \pm 1.4$ & $304 \pm 59$ & 92400 \\
\hline $\mathrm{ADP}$ & 27 & $26 \pm 4$ & $4.4 \pm 0.2$ & $201 \pm 30$ & 21400 \\
\hline
\end{tabular}

${ }^{a}$ Neither the purified nor the expressed enzymes displayed significant activity over ADP-glucose, UDP-glucose, CDP-glucose, CDP, CMP and AMP $(<3 \%)$.

${ }^{\mathrm{b}}$ Taken from [19].

${ }^{c}$ Means \pm S.D. of 3 experiments; $100 \%$ was $23 \mu \mathrm{mol} / \mathrm{min} / \mathrm{mg}$; protein assayed according to [50].

${ }^{\mathrm{d}}$ Kinetic parameters are expressed \pm S.E. of the pooled data of 2-3 experiments [24]. 


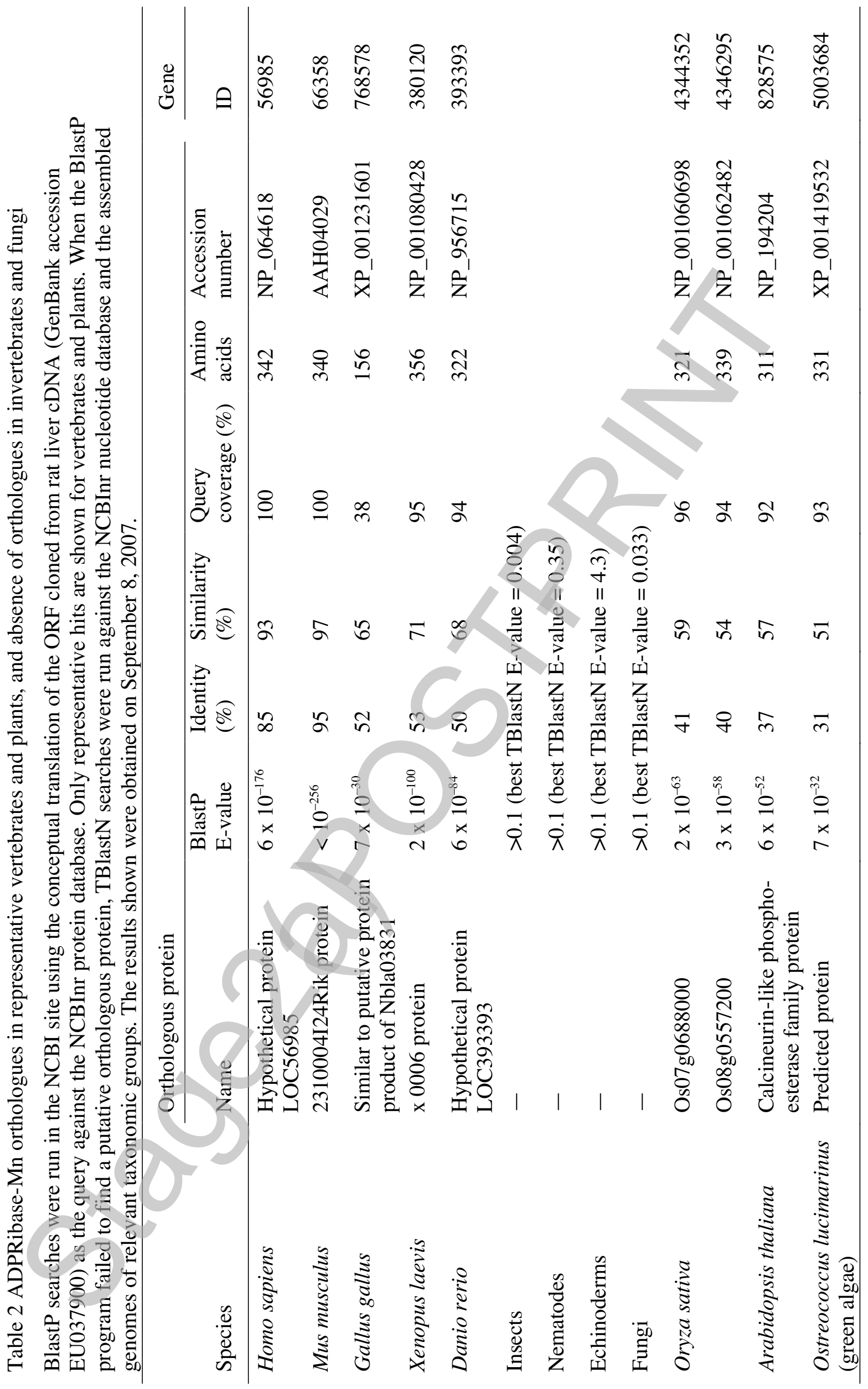


Table 3 ADPRibase-Mn profile neighbours of expression among the genes preferentially expressed in mouse immune cells and tissues

The list was found by automatically seaching for 2310004I24Rik gene profile neighbours in the GEO dataset GDS2068 within the GEO Profiles database at the NCBI site. Out of the 31 records found, only those classified as 'immune genes' are listed together with their assigned functions [37]. Expression profiles are shown in Figure S5.

\begin{tabular}{|c|c|c|}
\hline Gene symbol & Full name & $\begin{array}{l}\text { Assigned } \\
\text { function }\end{array}$ \\
\hline $\mathrm{Cd} 53$ & CD53 antigen & signaling \\
\hline Coro1a & coronin, actin binding protein $1 \mathrm{~A}$ & signaling \\
\hline $\begin{array}{l}\text { 1200013B08Rik } \\
\text { (Sly1) }\end{array}$ & RIKEN cDNA 1200013B08 gene & signaling \\
\hline Adcy7 & adenylate cyclase 7 & signaling \\
\hline Ptprcap & $\begin{array}{l}\text { protein tyrosine phosphatase, receptor type, C } \\
\text { polypeptide-associated protein }\end{array}$ & signaling \\
\hline Syk & spleen tyrosine kinase & signaling \\
\hline $\mathrm{Cd} 37$ & CD37 antigen & signaling \\
\hline Ptprc & protein tyrosine phosphatase, receptor type, $\mathrm{C}$ & signaling \\
\hline I12rg & interleukin 2 receptor, gamma chain & signaling \\
\hline $\mathrm{H} 2-\mathrm{Eb} 1$ & histocompatibility 2 , class II antigen $\mathrm{E}$ beta & immune \\
\hline $\mathrm{H} 2-\mathrm{Oa}$ & histocompatibility $2, \mathrm{O}$ region alpha locus & immune \\
\hline $\mathrm{H} 2-\mathrm{Ob}$ & histocompatibility 2, O region beta locus & immune \\
\hline $\mathrm{Cd} 79 \mathrm{~b}$ & CD79B antigen & immune \\
\hline Ms4a1 & $\begin{array}{l}\text { membrane-spanning 4-domains, subfamily A, } \\
\text { member } 1\end{array}$ & immune \\
\hline Ms4a4b & $\begin{array}{l}\text { membrane-spanning 4-domains, subfamily A, } \\
\text { member } 4 \mathrm{~B}\end{array}$ & immune \\
\hline Ncf4 & neutrophil cytosolic factor 4 & defense \\
\hline Sp100 & nuclear antigen Sp100 & cell cycle \\
\hline Ifi203 & interferon activated gene 203 & apoptosis \\
\hline Itgb2 & integrin beta 2 & adhesion \\
\hline Pou2af1 & POU domain, class 2, associating factor 1 & transcription \\
\hline Tap1 & $\begin{array}{l}\text { transporter 1, ATP-binding cassette, sub-family B } \\
\text { (MDR/TAP) }\end{array}$ & transport \\
\hline Nup210 & nucleoporin 210 & nuclear pore \\
\hline
\end{tabular}


Table 4 Preferential expression of ADPRibase-Mn activity in rat immune tissues The activities were quantitated after separation of the three ADPRibases by gelfiltration of tissue supernatants followed by ion-exchange chromatography (Figure S6). The results are referred to an amount of tissue containing $1 \mathrm{~g}$ protein (assayed in the crude homogenates), and are means \pm S.D. of three independent experiments, each corresponding to one animal.

\begin{tabular}{lccc}
\hline & ADPRibase-I & $\begin{array}{c}\text { ADPRibase-Mn } \\
\text { milliunits / } g \text { tissue protein }\end{array}$ & ADPRibase-II \\
\hline Thymus & $470 \pm 140$ & $330 \pm 80$ & $170 \pm 30$ \\
Spleen & $500 \pm 80$ & $300 \pm 50$ & $160 \pm 60$ \\
Splenocytes & $410 \pm 40$ & $550 \pm 190$ & $190 \pm 30$ \\
Liver & $590 \pm 140$ & $130 \pm 30$ & $270 \pm 70$ \\
Skeletal muscle & $180 \pm 20$ & $70 \pm 20$ & $60 \pm 10$ \\
\hline
\end{tabular}


Figure 1 Inactivation of recombinant ADPRibase-Mn by $o$-phenanthroline Enzyme samples were diluted 1:1 in $5 \mathrm{mM}(\bullet) o$-phenanthroline or $(O)$ EDTA each dissolved in $50 \mathrm{mM}$ Tris, $\mathrm{pH} 7.5$, and were incubated for the indicated lengths at $37^{\circ} \mathrm{C}$. Enzyme aliquots were taken at the end of the incubation, diluted 100-fold in $50 \mathrm{mM}$ Tris- $\mathrm{HCl}, \mathrm{pH} 7.5$, and immediately used for ADP-ribose hydrolase activity assay by HPLC.

Figure $2 \mathrm{pH}$ profiles of the activities of recombinant ADPRibase-Mn

Initial rates of hydrolysis were measured with the indicated substrate, in the presence of $1 \mathrm{mM} \mathrm{MnCl}$. The buffers used were: $100 \mathrm{mM}$ Tris-acetate ( $\mathrm{pH} \mathrm{6-7),} 100 \mathrm{mM}$ Tris- $\mathrm{HCl}$ (pH 7-9) and $100 \mathrm{mM}$ CAPS/NaOH (pH 9-10.1). Reaction mixtures of $0.4 \mathrm{ml}$ were prepared and, at the end of the incubation period, $0.1 \mathrm{ml}$ was used for the assay of activity, and $0.3 \mathrm{ml}$ for $\mathrm{pH}$ mesurement with a glass electrode.

Figure 3 Protein alignment of rat ADPRibase-Mn orthologues showing the conservation of a metallophosphoesterase sequence signature

The sequences were aligned using the Clustal-W program. Orthologous proteins (with Genbank accession numbers): Rnor, Rattus norvegicus (conceptual translation of EU037900); Hsap, Homo sapiens (NP_064618); Mmu, Mus musculus (AAH04029); Xlae, Xenopus laevis (NP_001080428); Drer, Danio rerio (NP_956715); Atha, Arabidopsis thaliana (NP_194204); Osat1 and Osat2, Oryza sativa (NP_001060698 and NP_001062482); Oluc, Ostreococcus lucimarinus (green algae) (XP_001419532). The asterisks and the points below the sequences mark residues conserved as identities or similarities, respectively. The white letters on dark background represent conserved amino acids that are part of the metallophosphoesterase sequence signature divided in five regions (I-V): DX[H/X]-(X)n-GDXX[D/X]-(X)n-GNH[D/E]-(X)n-[G/X]H-(X)n$\mathrm{GHX}[\mathrm{H} / \mathrm{X}]$ [32-35]. The vertical marks at the top of the sequences are positioned at intervals of ten amino acids relative to the Rattus norvegicus sequence.

Figure 4 Theoretical model of rat ADPRibase-Mn with docked ADP-ribose

The figure shows different views of the lowest-energy pose found after docking as described in the Experimental section. The two $\mathrm{Zn}^{2+}$ ions are shown as yellow spheres and ADP-ribose is shown in blue (adenine), red (pyrophosphate) and green (ribose-1 and ribose-2, respectively proximal and distal to the adenine). Oxygen atoms of the $\beta$ phosphate group interact with $\mathrm{Zn} 1$ and $\mathrm{Zn} 2$. (A) Full homology model showing the $\alpha / \beta / \beta / \alpha$ fold, typical of metallophosphoesterases, and the docked ADP-ribose. (B) Molecular surface of the active centre with ADP-ribose, as viewed from above in A. (C) Stereo view of a selection of amino acids that form the dimetallic centre and/or might interact with the substrate, as viewed from the right-hand side in A. Possible interactions of amino acid side chains in $\mathrm{C}$ are as follows. (i) Coordination with Zn1: Asp25, Gln27, Asp74 and His280. (ii) Coordination with Zn2: Asp74, Asn110, His241 and His 278. (iii) $\mathrm{H}$ bridge with O-P $\beta$ : Gln27, His 278 and His280. (iv) H bridge with OPa: Arg43 and His111. (v) H bridge with the phosphoanhydride O: Asn110 and His111. (vi) Hydrophobic contact with the adenine rings: Leu196. (vii) Contacts with ribose-1 or ribose-2 rings: Phe210 and Cys253, respectively. All the mentioned amino acids are 
sequentially conserved (Figure 3 ) and superimposable to those of the zebrafish protein (not shown), except Leu196 that is conserved but not superimposable in both proteins.

Figure 5 The rat ADPRibase-Mn gene and orthologues in mouse and human genomes

The exon(black boxes)-intron(thin lines) structures are shown as they currently appear in the NCBI Gene database, including the ORFs coding for rat ADPRibase-Mn and its mouse and human orthologues after splicing. The exons of the rat gene are currently supported by a $1.3 \mathrm{~kb}$ mRNA (BC088174) which agrees with the size of the most abundant transcript seen in a northern blot (Figure 6). The white prolongations of the first translated exon show how the mRNAs would remain after operation of the alternative $5^{\prime}$-splice in the next intron (see the text). The alternative splicing would give rise to proteins shorter than ADPRibase-Mn and its orthologues, due to an in-frame stop codon either in the portion of intron retained as exon (mouse and human) or in the next exon (rat).

Figure 6 Expression of $R G D 1309906$ transcripts in rat tissues

A multiple rat-tissue northern blot is shown after hybridisation with digoxineninlabelled ADPRibase-Mn cDNA. The figure shows a 3-h exposure of X-ray film to the chemiluminescent membrane, made 19-h after starting the detection reaction. Numbers below the lanes represent the quantitation (as percentages of the thymus signal) of the 1.4-kb band by image analysis during the first $3 \mathrm{~h}$ of detection. 


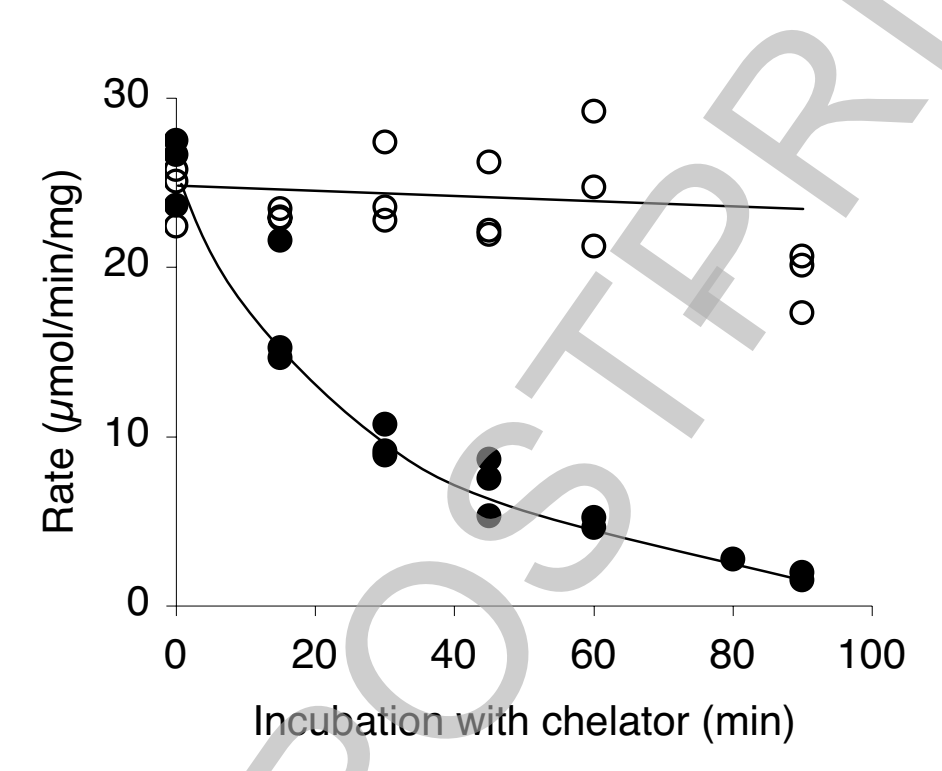


Figure 2

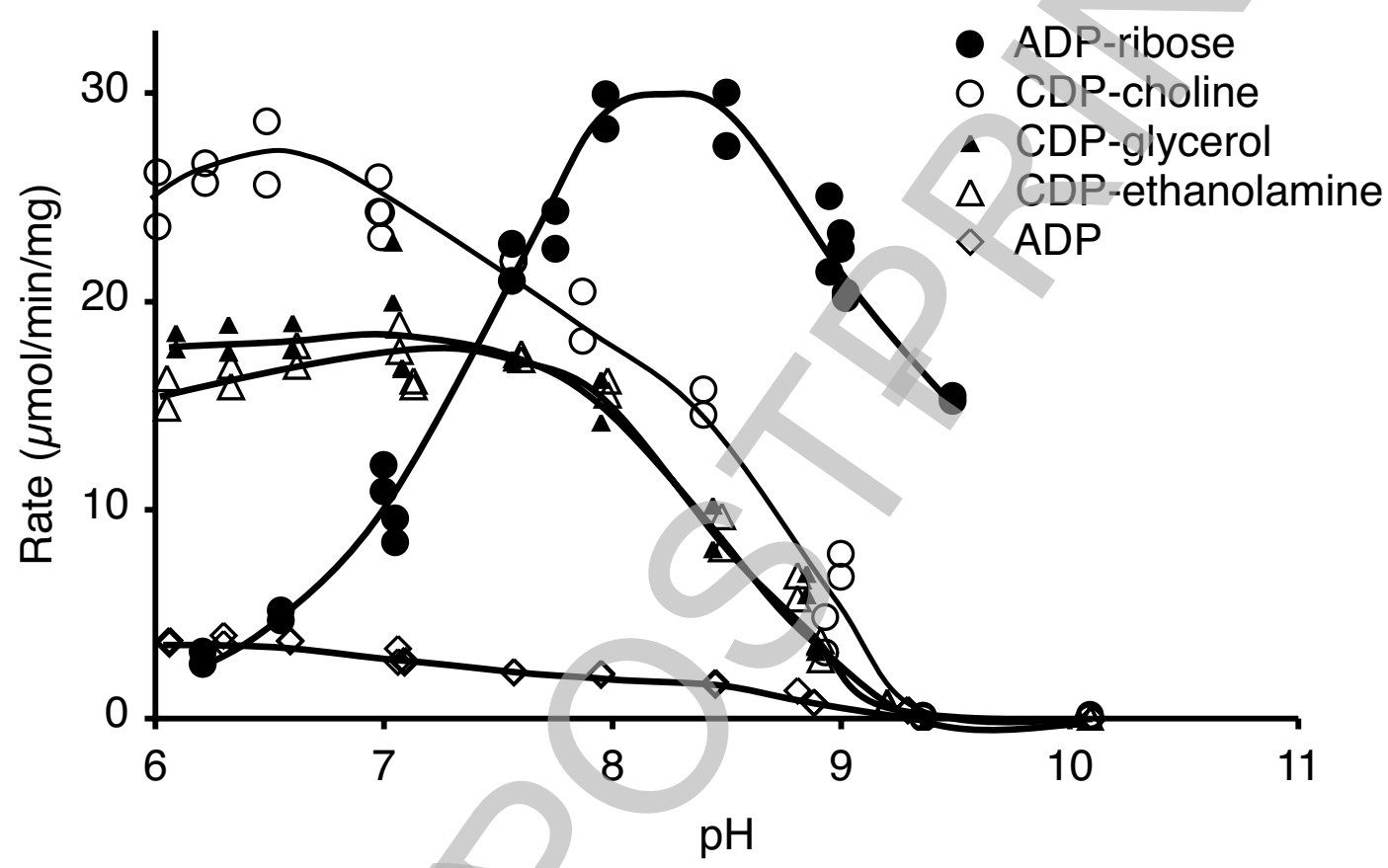




\section{Figure 3}

$\begin{array}{llr} & & \mid \\ \text { Rnor } & 1 & \text { MADKPDPSSPADGEPLFSFGVIADI } \\ \text { Hsap } & 1 & \text { MDDKPNPEALSDSSERLFSFGVIADV } \\ \text { Mmus } & 1 & \text { MADKLVPSSPADASEPLFSFGVIADI } \\ \text { Xlae } & 1 & \text { MFNLCYKGQKLQRIVQSKRMEEPFTFGIIADI } \\ \text { Drer } & 1 & \text { MEDPVFTFGLIADV } \\ \text { Atha } & 1 & \text { MGSAA-RQPLFSFGVIADVC } \\ \text { Osat1 } & 1 & \text { MMAVN---GVIHASS-REPLFSFGVIADV } \\ \text { Osat2 } & 1 & \text { MLVQPPNAVAVRATAAGKPLFSFGVIADVC } \\ \text { Oluc } & 1 & \end{array}$

IDLEDGYNFQRSRRRCYRHSLVHLQGA IEDWNKES-----FADLEDGFNFQGTRRRYYRHSLLHLQGAIEDWNNES------ADLEDGYNYQRSRRRYYRHSLIHLQGAIEDWNKES------YADKDNRLNYLKT SMRYYRNSLTQLKVAIKEWATES------YADIEDGENYLRTRRRYYRGSADLLRDAVLQWRRE-------YADISDGRS FLGVP-RYYRNS I LVLQRAVETWNQH-------YADI PDGRSFLGVP-RYYRHS I SVLQRAVSTWNKQ-------YADI PDGRSFLGVP-RYYRHSLTILQRAVRSWNAHNHKHPVAG SREPHFRFGLLADIQY

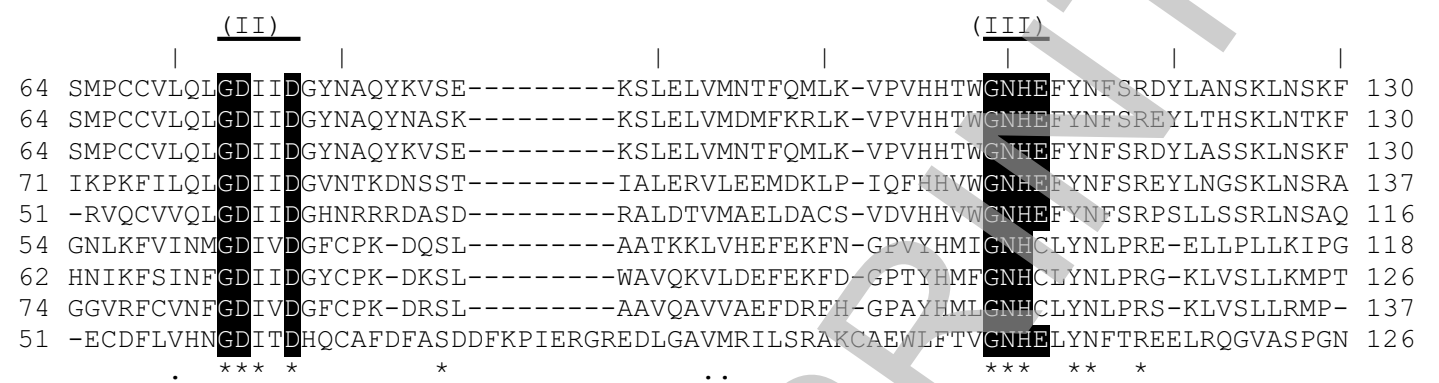

131 LEDQIPQHPETTPS-----ENYYAYHFVPFPKFRFILLDSYDLSVLGIDQFSPKYEQCMKILREHNPN-VELNSPQG 201 131 LEDQIVHHPETMPS-----EDYYAYHFVPFPKFRFILIDAYDLSVLGVDQSSPKYEQCMKILREHNPN-TELNSPQG 201 131 LEDQIAQHPETTPS-----ENYYAYHFVPFPKFRFILLDSYDLSVLGIDPSS PKYEQCMKMLREHNPN-VELNSPQG 201 138 RENRIDQQVGTSESGETNDESFYAYHFSPFPKFRFLLIDGYDLSPIGREKTSLKYDISFNLLKEKNPN-EDLNSPTG 213 117 R------TGTDTGSDLIGDDIYAYEFSPAPNFREVLLDAYDLSVIGREEESEKHTHSWRILTQHNHNLQDLNLPPV 186 119 R---------------DGNAYYDFSPTPEYRVVVLDGYDI SAVGWPQEHPNTIAALKILEEKNPN-TDKNSPAG 176 127 D----------SDRAYYDFSPCPEYREVVLDAYDFSALGWPRDHPVTAEAMKFLEEKNPN-SDKNSPDG 184 138 ----------SGRAYYDFSPFPGYRFVVLDAYDFSAVGWPRGHPVAAAARRFLDERNPN-ADKNSPSG 194 127 S------LNLKCSN---ADGEFYYSFKAGPGWRVMVLDPYAVS I YRKGRQQGLCEEAVELLRKHNPN-VDLFVKEN 192 * $\star$

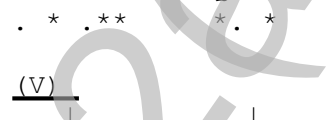


Figure 4
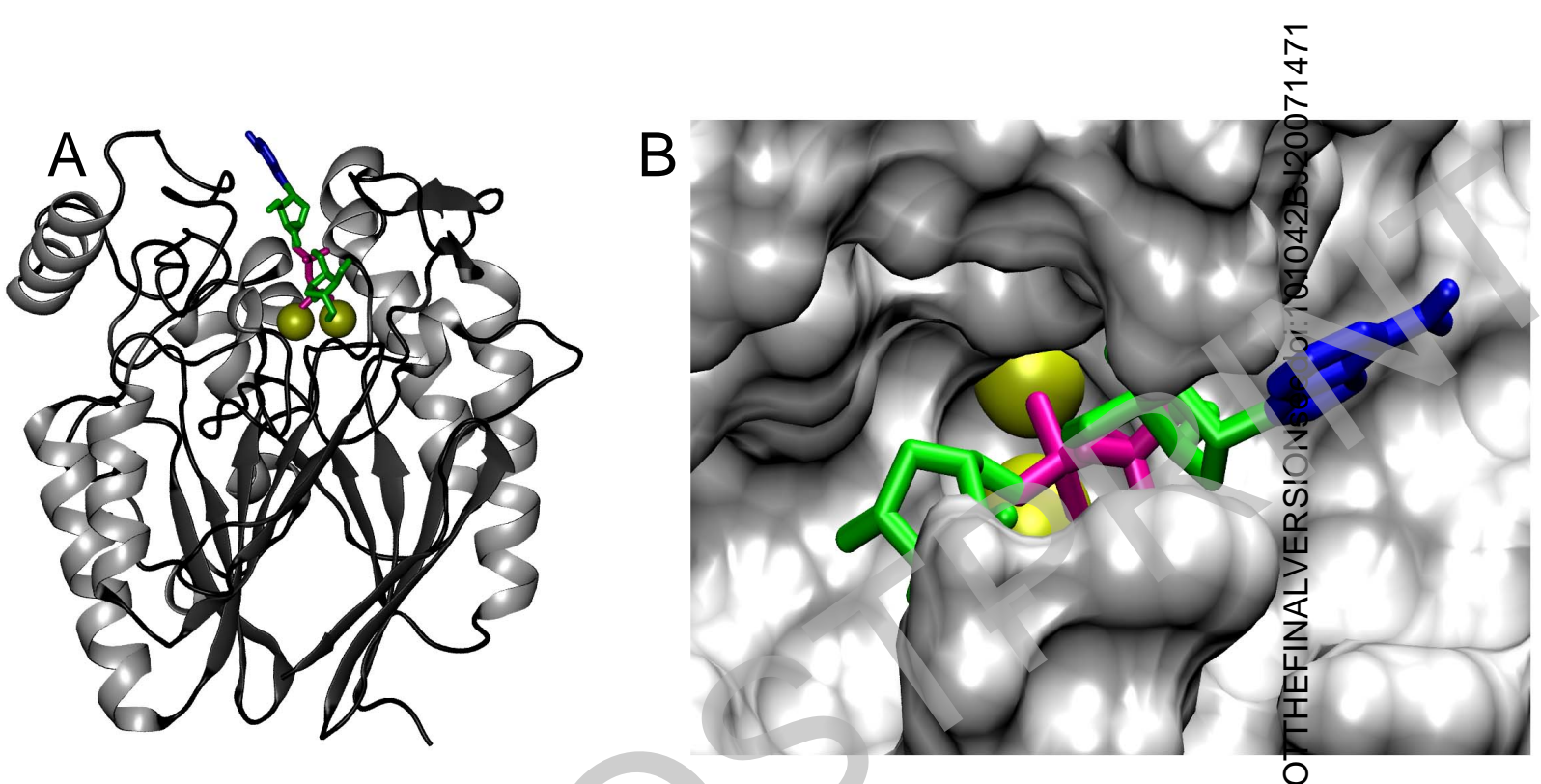

c
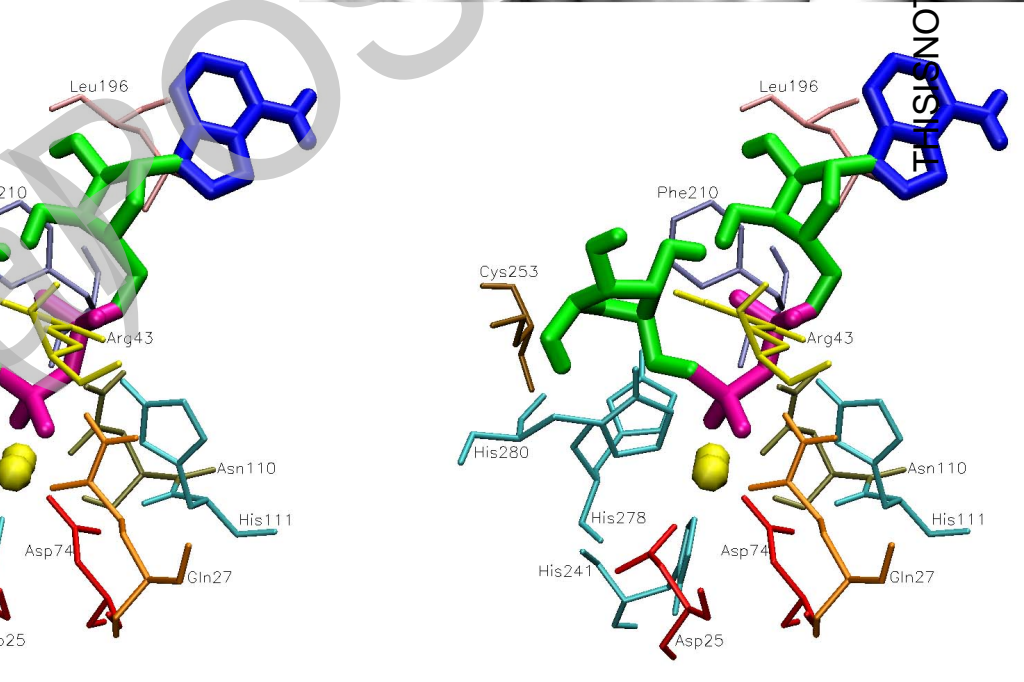
Figure 5

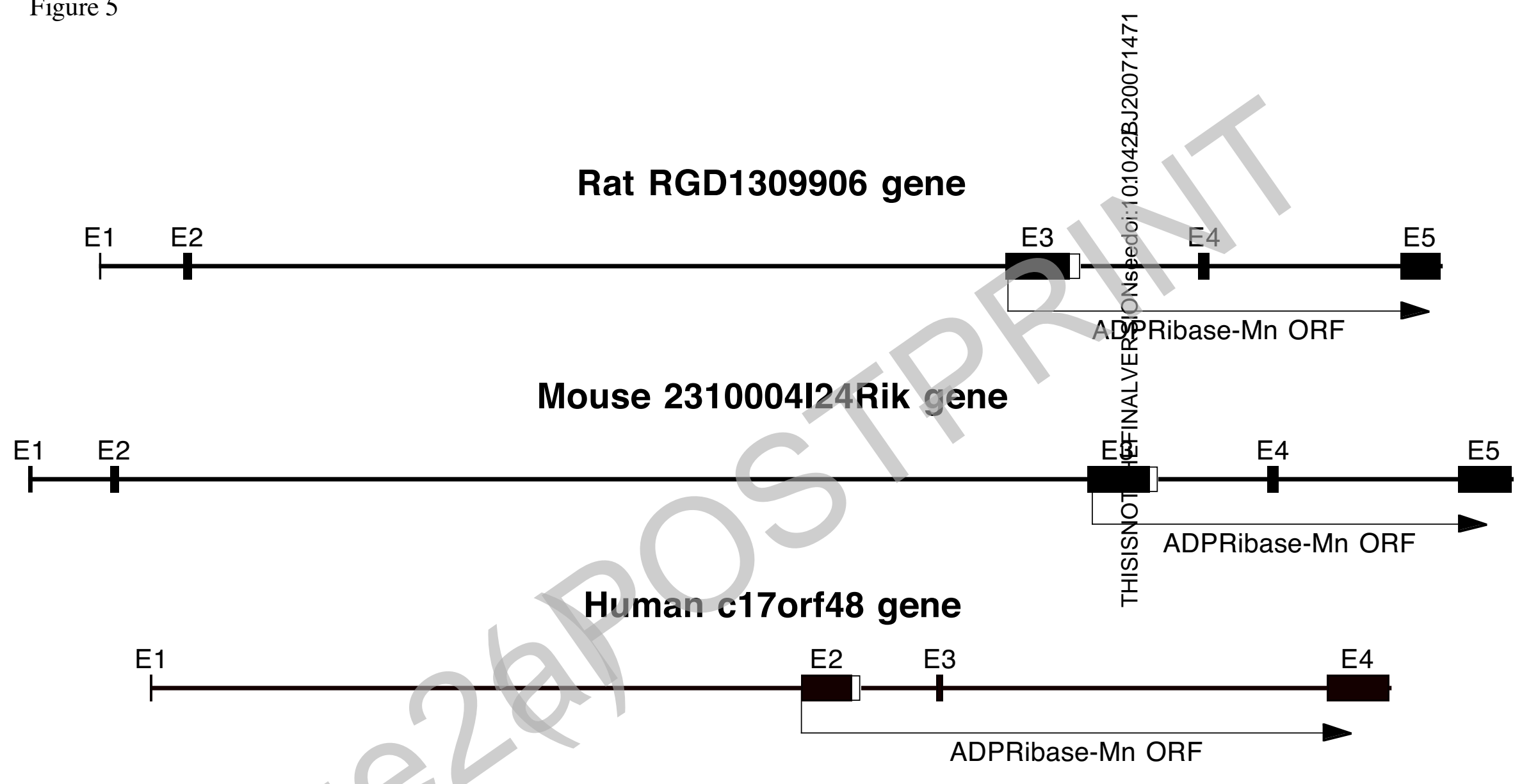


Figure 6 